\title{
ANÁLISE DA TECTÔNICA RÚPTIL EM ROCHAS DO EMBASAMENTO DA BACIA DE CURITIBA COM VISTAS À DETERMINAÇÃO DE ÁREAS FAVORÁVEIS À EXPLORAÇÃO DE ÁGUA SUBTERRÂNEA
}

\author{
Lílian Chavez*
}

\author{
DISSERTAÇÃO DE MESTRADO - Programa de Pós-Graduação em Geologia - UFPR \\ DATA DE DEFESA: 22 abr. 2003
}

\begin{abstract}
A área de estudo abrange o município de Curitiba (PR) e parte dos municípios circunvizinhos, englobando geologicamente o embasamento da Bacia Sedimentar de Curitiba (Complexo Atuba). O objetivo central desta pesquisa é apontar parâmetros que possam indicar a favorabilidade na exploração de água subterrânea no aqüífero fraturado da bacia caracterizado pelo embasamento. Para tanto, foram utilizadas técnicas de análise estrutural tendo por base dados da tectônica e da morfotectônica local. Como ferramentas de modelagem, foram aplicadas a estatística clássica, a geoestatística e Sistemas de Informações Geográficas (SIGs). Estudos anteriores, realizados por outros pesquisadores, indicam que o aqüífero fraturado em questão é condicionado por domínios estruturais que integram grandes sistemas estruturais regionais, estudados pela análise da deformação rúptil, que engloba a definição dos mecanismos estruturais cinemáticos e dinâmicos da trama de fraturas da região de Curitiba e arredores. Neste sentido, foi dada ênfase à análise estrutural dos diferentes conjuntos e famílias de fraturas encontradas principalmente em rochas do embasamento. As observações em campo indicam a existência de padrões estruturais aos quais estão associados sistemas de cisalhamento rúpteis abertos, que servem de condutos preferenciais para a circulação da água subterrânea. As informações obtidas foram organizadas dentro de banco de dados georeferenciados de forma a serem tratadas e analisadas adequadamente pela confecção de diagramas de rosetas e projeções estereográficas por meio de softwares apropriados. As descontinuidades em que há maior fluxo
\end{abstract}

da água subterrânea, indicando, conseqüentemente as áreas de maior potencial no aqüífero, são aquelas de direção N-S, NE-SW e NW-SE, sendo esse potencial ainda maior na conexão dessas estruturas. Paralelamente ao uso do SIG, a criação de Modelos Digitais de Relevo (MDRs) permitiu investigar feições geomorfológicas na área de estudo, com ênfase no traçado dos lineamentos estruturais e traçado automático da rede de drenagens, utilizando e adaptando funções avançadas do software ArcView GIS 3.2Ò. A identificação e reclassificação dos traços de fraturas são importantes para definir as propriedades e características que possibilitam a circulação de água subterrânea. Além disso, foi atualizado e reorganizado o banco de dados hidrogeológicos contendo informações referentes a 1297 poços tubulares profundos no município de Curitiba e arredores, perfurados entre o período de 1950 até o ano de 2001. Posteriormente, com a modelagem geoestatística, buscou-se encontrar um modelo que melhor se ajustasse aos valores de vazões de 459 casos para então aplicar o método convencional da krigagem, resultando em importantes referenciais nas análises integradas na pesquisa. Finalmente, com o SIG, foi possível realizar o cruzamento das análises estruturais e análises espaciais, contendo a localização dos poços tubulares profundos, resultando em informações preliminares que apontam uma relação entre locais onde há altas vazões e grandes alinhamentos estruturais de direção N-S, o que indica que essas estruturas geológicas servem como condutos para o fluxo de água subterrânea.

*E-mail: isollde@uol.com.br 